\title{
Soil methane oxidation in a long-term no-tillage system in Southern Brazil
}

\section{Oxidação de metano em solo a longo prazo sob plantio direto no Sul do Brasil}

\author{
Cimélio Bayer ${ }^{1 *}$; Juliana Gomes ${ }^{1}$; Frederico Costa Beber Vieira ${ }^{2}$; \\ Josiléia Accordi Zanatta ${ }^{3}$; Marisa de Cássia Piccolo ${ }^{4}$; Jeferson Dieckow ${ }^{5}$
}

\begin{abstract}
Conservation management systems are usually suggested as alternative to restore the soil methane $\left(\mathrm{CH}_{4}\right)$ oxidation capacity of degraded soils; however, little information is available on tropical and subtropical soils. Our objective was to evaluate the long-term (19 years) effect of no-tillage (NT) versus conventional tillage (CT) management systems on $\mathrm{CH}_{4}$ fluxes in a formerly degraded Acrisol in Southern Brazil. Annual $\mathrm{CH}_{4}$ fluxes of two cropping systems [O/M-black oat (Avena strigosa)/maize and V/M-vetch (Vigna sativa)/maize] were measured in NT and CT soils. Static chambers were used for air sampling, while chromatography was used for $\mathrm{CH}_{4}$ analysis. Analysis of the historical dataset at this experimental site indicated improvements in soil quality under the NT system, especially in legumebased cropping system $(\mathrm{V} / \mathrm{M})$ that exhibited the highest annual biomass input. $\mathrm{CH}_{4}$ fluxes ranged from $-42 \pm 2$ to $38 \pm 16 \mu \mathrm{g} \mathrm{C} \mathrm{m}^{-2} \mathrm{~h}^{-1}$, and annual $\mathrm{CH}_{4}$ emissions ranged from $-825 \pm 117$ (CT V/M) to $453 \pm$ $185 \mathrm{~g} \mathrm{C} \mathrm{ha}^{-1}(\mathrm{NT} \mathrm{O} / \mathrm{M})$. Thus, the annual $\mathrm{CH}_{4}$ oxidation capacity of the soil was not related to the soil quality produced by the soil management systems. On the basis of our results and published literature, we postulate that conservation management systems improve the methane oxidation and soil quality in distinct soil layers, which result in a slow effect of these management systems on the methane oxidation capacity.
\end{abstract}

Key words: Global warming, tillage systems, tropical soils, cropping systems

\section{Resumo}

Sistemas conservacionistas de manejo de solo são considerados usualmente uma alternativa para restaurar a capacidade de solos agrícolas degradados em oxidar metano $\left(\mathrm{CH}_{4}\right)$, mas escassa informação é disponível para solos tropicais e subtropicais. O objetivo do presente estudo foi avaliar o efeito de longo prazo (19 anos) do plantio direto (PD) nos fluxos de $\mathrm{CH}_{4}$ em um Argissolo Vermelho (Classificação Brasileira) degradado da região Sul do Brasil, em comparação ao preparo convencional (PC). Fluxos anuais de $\mathrm{CH}_{4}$ do solo foram avaliados nos sistemas PD e PC sob dois sistemas de cultura (aveia/ milho- A/M e ervilhaca/milho-E/M). Amostragem do ar foi conduzida utilizando o método da câmara

\footnotetext{
${ }^{1}$ Profs. Associados, Universidade Federal do Rio Grande do Sul, UGRGS, Dept ${ }^{\circ}$ de Solos, 91540-000, Porto Alegre, RS. Brazil. E-mail: cimelio.bayer@ufrgs.br; ju.gomes@gmail.com

${ }^{2}$ Prof. Adjunto, Universidade Federal do Pampa, UNIPAMPA, Av. Antonio Trilha, 1847, 97300-000, São Gabriel, RS, Brazil. E-mail: fredericovieira@unipampa.edu.br

${ }^{3}$ Pesquisadora, Empresa Brasileira de Pesquisa Agropecuária, EMBRAPA, Centro Nacional de Pesquisa de Florestas, 83411-000, Colombo, PR, Brazil. E-mail: josileia.zanatta@embrapa.br

${ }^{4}$ Prof ${ }^{a}$ Livre-Docente, Universidade de São Paulo, USP, Centro de Energia Nuclear na Agricultura, 13416-000, Piracicaba, SP, Brazil. E-mail: mpiccolo@cena.usp.br

${ }^{5}$ Prof. Adjunto, Universidade Federal do Paraná, UFPR, Dept ${ }^{\circ}$ de Solos e Engenharia Agrícola, 80035-050, Curitiba, PR, Brazil. E-mail: jefersondieckow@ufpr.br

* Author for correspondence
} 
estática fechada e as análises de $\mathrm{CH}_{4}$ foram realizadas por cromatografia gasosa. Dados históricos do experimento evidenciaram melhoria expressiva da qualidade do solo em PD, especialmente quando associado ao sistema de cultura com leguminosas de cobertura de solo (E/M) que apresentou a mais elevada adição anual de biomassa ao solo. Os fluxos de $\mathrm{CH}_{4}$ variaram de $-42 \pm 2$ a $38 \pm 16 \mu \mathrm{g} \mathrm{C} \mathrm{m}^{-2} \mathrm{~h}^{-1}$ e as emissões anuais de $\mathrm{CH}_{4}$ variaram de $-825 \pm 117$ (PC E/M) a $453 \pm 185 \mathrm{~g} \mathrm{C}^{-1}$ (PD A/M). Portanto, a capacidade de oxidação de $\mathrm{CH}_{4}$ não teve relação com a qualidade do solo nos distintos sistemas de manejo. Baseado nos resultados do presente estudo e da literatura, nos hipotetizamos que as zonas de oxidação de $\mathrm{CH}_{4}$ e de melhoria da qualidade do solo ocorrem em posições distintas no perfil do solo sob sistemas conservacionistas de manejo, determinando que a recuperação da capacidade do solo em oxidar $\mathrm{CH}_{4}$ seja bastante lenta.

Palavras-chave: Aquecimento global, preparos de solo, solos tropicais, sistemas de cultura

\section{Introduction}

Methane $\left(\mathrm{CH}_{4}\right)$ is one of the main anthropogenic greenhouse gases (GHG), with atmospheric concentrations increasing at the rate of $1 \%$ per year (IPCC, 2007). Soils are the only biological sink for $\mathrm{CH}_{4}$ (SMITH et al., 2000); yet, the cultivation of undisturbed soils causes a significant decrease in soil $\mathrm{CH}_{4}$ sink strength (POWLSON et al., 1997; JACINTHE; LAL, 2005; JACINTHE; LAL, 2006; MOJEREMANE; REES; MENCUCCINI, 2010). Ploughing and disking appear to be the main causes for this decline, in addition to artificial $\mathrm{N}$ fertilization practices (HÜTSCH, 1998; SUWANWAREE; ROBERTSON, 2005; ACTON; BAGGS, 2011; STIEHL-BRAUN et al., 2011). Soil disturbance by conventional tillage (CT) systems creates an inhospitable environment for methanotrophic organisms (WILLISON et al., 1995; HÜTSCH, 2001). Furthermore, ammonium-based $\mathrm{N}$ fertilizers inhibit soil $\mathrm{CH}_{4}$ oxidation because of competition between the nitrification and $\mathrm{CH}_{4}$ oxidation processes by methane-mono-oxygenase enzymes (MAXFIELD et al., 2011).

Reduced and no-tillage (NT) systems are usually suggested as alternative practices for restoring the $\mathrm{CH}_{4}$ uptake capacity of soils (BALL; SCOTT; PARKER, 1999; HÜTSCH, 2001). This is because the improvement of soil quality via these practices is beneficial to microorganisms in general, including methanotrophs (HÜTSCH, 1998; HÜTSCH, 2001). Previous studies have reported that the NT system has a positive effect on restoring the $\mathrm{CH}_{4}$ oxidation capacity of soils (HÜTSCH, 1998; KESSAVALOU et al., 1998; USSIRI; LAL; JARECKI, 2009); however, these effects are considered to be extremely slow, with several decades being necessary for NT soil to become a significant $\mathrm{CH}_{4}$ sink (JACINTHE; LAL, 2005; JACINTHE; LAL，2006; ELDER; LAL, 2008; REGINA; ALAKUKKU, 2010).

Long-term cropping systems may also influence the $\mathrm{CH}_{4}$ oxidation capacity of soils; however, available published literature on these systems remains scarce. High biomass-C input cropping systems may have a positive effect on soil $\mathrm{CH}_{4}$ oxidation as this system is known to improve soil quality (HÜTSCH, 2001). However, this beneficial effect of high $\mathrm{C}$-input cropping systems may be partially off-set by methanogenesis, which occurs when a large amount of labile $\mathrm{C}$ is applied to a restricted layer of the soil (BAGGS; CHEBII; NDUFA, 2006) or to soils with high soil moisture levels (MCLAIN; AHMANN, 2008). Biologically fixed $\mathrm{N}$ inputs may generate short-term effects on $\mathrm{CH}_{4}$ oxidation, similar to the effects of ammoniumbased fertilizers (BOECKX; VANCLEEMPUT; VILLARALVO, 1997). This effect occurs in addition to the long-term deleterious effect of repeated $\mathrm{N}$ input on $\mathrm{CH}_{4}$ oxidation, causing a shift in the composition of methanotroph populations (HÜTSCH, 2001; SUWANWAREE; ROBERTSON, 2005; MAXFIELD et al., 2011).

In this study, we aimed to evaluate the potential of recovering the $\mathrm{CH}_{4}$ oxidation capacity of a formerly degraded subtropical Acrisol in Southern Brazil by using long-term no-tillage under two cropping systems. In addition, historical data for this 
experiment were analyzed to support the discussion about the effect of soil management systems on soil quality and its possible relationship with annual $\mathrm{CH}_{4}$ fluxes.

\section{Material and methods}

\section{Characteristics of the experimental site}

The study was performed within the framework of a long-term experiment (19 years) at the Agronomic Experimental Station of the Federal University of Rio Grande do Sul (UFRGS; $30^{\circ} 06^{\prime} \mathrm{S}, 5^{\circ} 41^{\prime} \mathrm{W}$; $45 \mathrm{~m}$ altitude above sea level) in Southern Brazil. The local climate is subtropical (Cfa, Köppen), with an annual mean temperature of $19.4{ }^{\circ} \mathrm{C}$ and annual rainfall of $1440 \mathrm{~mm}$. The soil was a sandy clay loam Acrisol (IUSS, 2006), containing $220 \mathrm{~g} \mathrm{~kg}^{-1}$ of clay, and was derived from granite. In addition, this soil was physically degraded when the experiment was initiated in 1985. In 1969, the original grassland was converted into an annual cropland. This system was based on CT, which caused heavy erosion of the land because of the use of intense ploughing until the start of the experiment.

The experiment (which is still ongoing) includes three tillage systems, three cover-crop-based cropping systems and two levels of $\mathrm{N}$ fertilization, arranged in a split-plot randomized block design with three replicates. For the current study, NT and $\mathrm{CT}$ were evaluated in combination with two cropping systems under no $\mathrm{N}$ fertilization. The two cropping systems comprised (1) black oat (Avena strigosa Schreb.) as the winter cover-crop and maize (Zea mays L.) as the summer crop $[\mathbf{O} / \mathbf{M}]$ and (2) vetch (Vigna sativa L.) as the winter cover-crop and maize as the summer crop $[\mathbf{V} / \mathbf{M}]$.

The winter cover-crops were sown in April or May (autumn) by using a drill, while the maize was sown in September or October (spring) by using a row planter (60000 seeds/ha). In the CT plots, tillage operations were carried out in spring, before sowing the maize, and served the purpose of incorporating the winter cover-crops into the soil. Operations included one ploughing operation (disk plough, 17-cm depth) and two harrowing operations (disk harrow, 10-cm depth). At the same time, glyphosate herbicide (1.4 kg a.i./ha) was applied to the NT plots, with the winter cover-crops being managed using a knife-roller two to three days later. All aboveground residues were left on the soil surface. Additional information about the experiment can be obtained from the paper published by Zanatta et al. (2007).

\section{Air sampling and $\mathrm{CH}_{4}$ analysis}

Fourteen air sampling events were performed during a 344-day period, from November 5, 2003 (4 days after cover-crop management) to October 13, 2004. The sampling events were conducted at weekly intervals during the first 45 days, and then at intervals ranging from 15 to 60 days (Figure 1).

Six days before starting the air sampling, a miniplot of $2 \times 2 \mathrm{~m}$ was delimited within field replicates of each treatment. Two aluminum bases (collars) with an internal area of $0.0346 \mathrm{~m}^{2}$ were driven 5 $\mathrm{cm}$ into the soil of each mini-plot and were only removed for sowing or harvesting.

Air samples were obtained from PVC closed flux chambers (diameter, $0.25 \mathrm{~m}$; height, 0.20 $\mathrm{m})$, which were mounted on the aluminum bases (GOMES et al., 2009). The chamber and aluminum base were sealed with water. The temperature of the chamber headspace was monitored using a digital thermometer, and the air was homogenized using a $12-\mathrm{V}$ fan. Samples were collected at the top of the chamber using a $20-\mathrm{mL}$ polypropylene syringe. Each sampling session began at 0900, and samples were obtained at $0,15,30$, and $45 \mathrm{~min}$ after chamber closure.

The samples were immediately stored in a thermal box and transported by express mail to the Environmental Biogeochemistry Laboratory (Nuclear Energy Centre, University of Sao Paulo, Brazil) to analyze $\mathrm{CH}_{4}$ concentrations by using gas chromatography (GC-Shimadzu 14A), so that all samples were analyzed within a $24 \mathrm{~h}$ period after 
collection. The chromatograph was equipped with a Porapak-Q column set at $30^{\circ} \mathrm{C}, \mathrm{N}_{2}$ as the carrier gas $\left(30 \mathrm{~mL} \mathrm{~min}^{-1}\right)$, an injector temperature of $50^{\circ} \mathrm{C}$, and a flame ionization detector at $320^{\circ} \mathrm{C}$.

The $\mathrm{CH}_{4}$ fluxes were calculated using the following equation:

$$
f=\frac{\Delta C}{\Delta t} \times \frac{V}{A} \times \frac{m}{V m}
$$

where $f$ is the flux of soil $\mathrm{CH}_{4}\left(\mu \mathrm{g} \mathrm{CH}_{4}-\mathrm{C} \mathrm{m}^{-2} \mathrm{~h}^{-1}\right)$, $\Delta C / \Delta t$ is the rate of change of the gas concentration inside the chamber $\left(\mu \mathrm{g} \mathrm{CH}_{4}-\mathrm{C} \mathrm{h}^{-1}\right), V$ is the headspace volume of the chamber $\left(0.00982 \mathrm{~m}^{3}\right), A$ is the area of the aluminum-base $\left(0.0346 \mathrm{~m}^{2}\right), m$ is the molecular weight of the gas $\left(16 \mathrm{~g} \mathrm{~mol}^{-1}\right)$, and $\mathrm{Vm}$ is the molar volume of gas $\left(\mathrm{m}^{3} \mathrm{~mol}^{-1}\right)$ corrected for headspace chamber air temperature $(\mathrm{K})$ measured at the sampling time.

Mean $\mathrm{CH}_{4}$ fluxes $\left(\mu \mathrm{g} \mathrm{CH}_{4}-\mathrm{C} \mathrm{m}^{-2} \mathrm{~h}^{-1}\right)$ and standard error were calculated from the fluxes measured in the two chambers for each treatment. Daily $\mathrm{CH}_{4}-\mathrm{C}$ fluxes were estimated by linear interpolation, assuming that the 9:00 to 10:00 a.m. sampling period provided a valid estimation of the average daily flux (JANTALIA et al., 2008). Cumulative emissions for one year and for the post-management period (herein defined as the 90-day period after winter cover-crop management) were calculated by integrating the daily $\mathrm{CH}_{4}$ emissions.

Figure 1. Schedule for air sampling and agricultural practices.

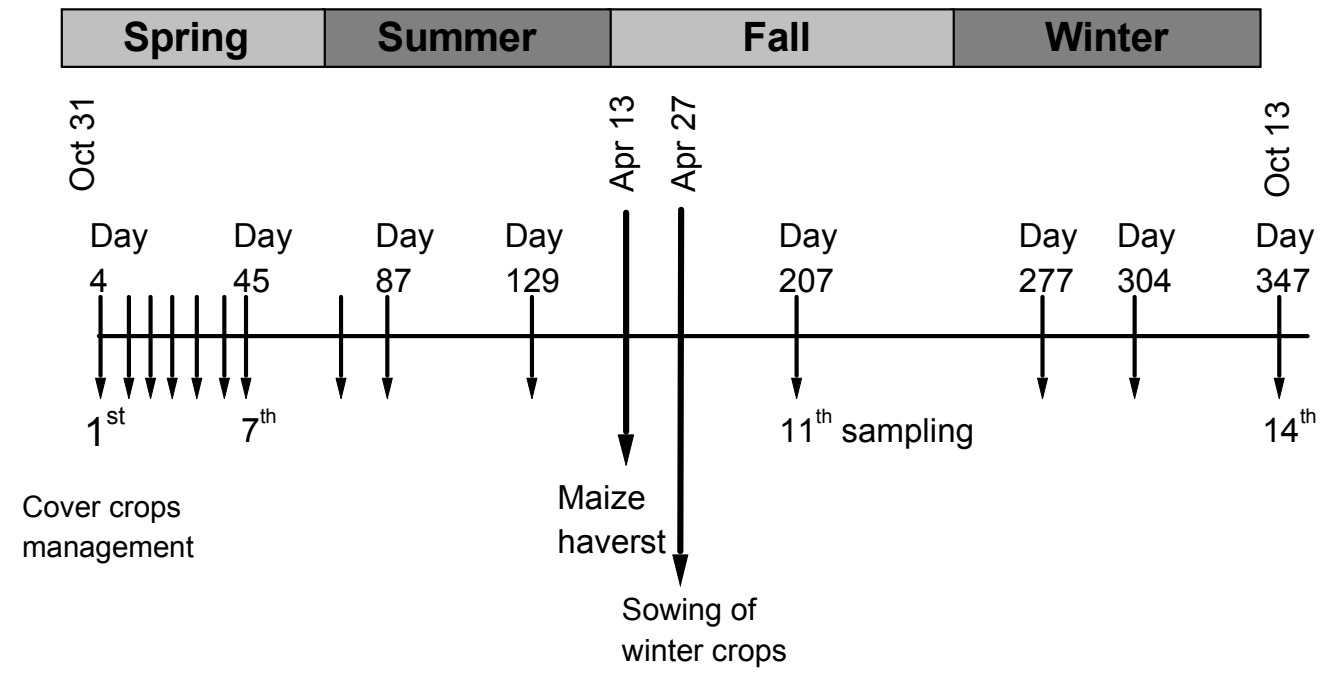

Source: Elaboration of the authors.

\section{Soil ammonium content}

Because of the recognized inhibitory effect of ammonium $\left(\mathrm{NH}_{4}^{+}\right)$on soil $\mathrm{CH}_{4}$ oxidation (MAXFIELD et al., 2011), the $\mathrm{NH}_{4}^{+}$content of the soil was determined during the first 11 air sampling events. Four sub-samples were collected in the 0-30-cm layer of the $2 \times 2$-m mini-plot. $\mathrm{NH}_{4}^{+}$was extracted using $1 \mathrm{M} \mathrm{KCl}$ and was determined using the Kjeldhal distillation method (MULVANEY, 1996).

\section{Air temperature and rainfall}

Air temperature and rainfall data (Figure 2) were collected from an automatic meteorological station (Department of Forage and Meteorology, UFRGS), which is located about $1 \mathrm{~km}$ from the experimental site. 
Figure 2. Air temperature and rainfall during the sampling period.

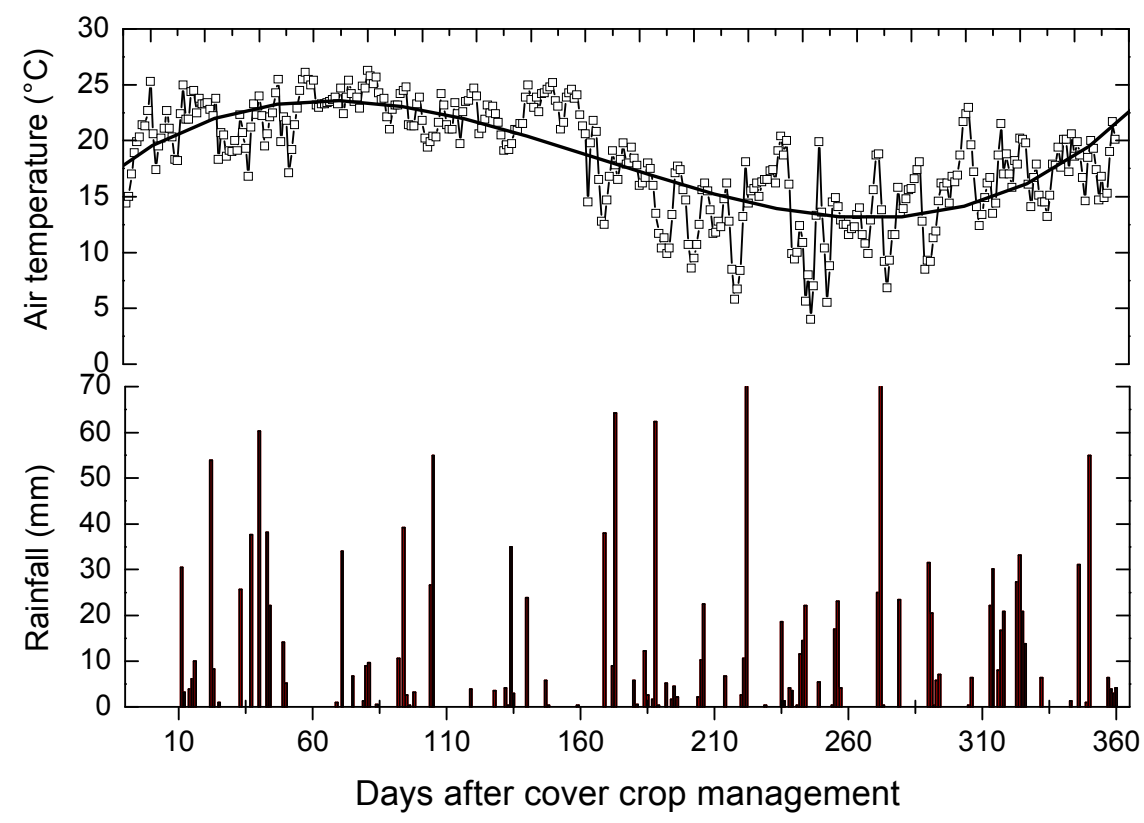

Source: Elaboration of the authors.

\section{Historical data for soil quality}

Historical data analysis on the long-term effect of soil management systems on biological, chemical, and physical soil quality indicators in the experimental area was conducted to verify the possible relationship of soil quality improvement and soil $\mathrm{CH}_{4}$ oxidation.

\section{Statistical analysis}

Annual soil $\mathrm{CH}_{4}$ fluxes were subjected to analysis of variance, and the difference between the means was evaluated using the Tukey test at 0.10 level. The relationship between soil $\mathrm{NH}_{4}^{+}$content and $\mathrm{CH}_{4}$ fluxes was evaluated by the significance of correlation coefficient (r). These analyses were conducted using SAS $^{\circledR}$ version 8.02.

\section{Results and Discussion}

Overview of historical data on how management systems affect soil quality

The historical analysis of soil quality under different soil management systems at the experimental site is summarized in Table 1. Compared to CT, NT greatly improved soil quality, especially when associated with the cropping system based on legume cover-crop (V/M), as evidenced by the highest stocks of total and labile organic $\mathrm{C}$, total soil $\mathrm{N}$, microbial biomass-C, soil aggregation and others soil quality indicators (Table 1). In general, the order of soil quality under the management systems was ranked as following: NT $\mathrm{V} / \mathrm{M}>\mathrm{NT} \mathrm{O} / \mathrm{M} \geq \mathrm{CT}$ V/M $>\mathrm{CT} \mathrm{O} / \mathrm{M}$. 
Table 1. Summary of the historical soil quality dataset from the long-term experiment conducted in Southern Brazil.

\begin{tabular}{|c|c|c|c|c|c|c|c|}
\hline \multirow{3}{*}{ Soil quality indicator $\dagger$} & \multirow{3}{*}{$\begin{array}{l}\text { Time } \$ \\
\text { (years) }\end{array}$} & \multirow{3}{*}{$\begin{array}{l}\text { Depth } \\
(\mathrm{cm})\end{array}$} & \multicolumn{4}{|c|}{ Soil Management System $\S$} & \multirow[t]{3}{*}{ Reference } \\
\hline & & & \multicolumn{2}{|c|}{$\begin{array}{l}\text { Conventional } \\
\text { tillage }\end{array}$} & \multicolumn{2}{|c|}{ No-tillage } & \\
\hline & & & $\mathrm{O} / \mathrm{M}$ & $\mathrm{V} / \mathrm{M}$ & $\mathrm{O} / \mathrm{M}$ & $\mathrm{V} / \mathrm{M}$ & \\
\hline Mean annual $\mathrm{C}$ input $\left(\mathrm{Mg} \mathrm{ha}^{-1}\right)$ & 19 & - & 4.07 & 5.79 & 4.02 & 5.58 & 1 \\
\hline $\begin{array}{l}\text { Mean annual } \mathrm{N} \text { input from cover crops } \\
(\mathrm{kg} / \mathrm{ha})\end{array}$ & 19 & - & 35 & 121 & 35 & 108 & 2 \\
\hline \multicolumn{8}{|l|}{ Biological } \\
\hline Microbial biomass (mg C kg-1 soil) & 11 & $0-15$ & 194 & - & 261 & - & 3 \\
\hline$\beta$-Glucosidase ( $\mu \mathrm{g}$ p-nitrophenol $\mathrm{g}^{-1}$ soil) & 20 & $0-20$ & 50 & - & 60 & - & 4 \\
\hline Diacetate Fluorescein $\left(\mu \mathrm{g} \mathrm{NH}_{4}^{+}-\mathrm{N} \mathrm{g}^{-1}\right.$ soil $)$ & 20 & $0-20$ & 630 & - & 620 & - & 4 \\
\hline \multicolumn{8}{|l|}{ Chemical } \\
\hline $\mathrm{SOC}$ (g C kg-1 soil) & 19 & $0-10$ & 8.95 & 10.20 & 11.43 & 14.40 & 1 \\
\hline Total soil N ( $\mathrm{g} \mathrm{N} \mathrm{kg}^{-1}$ soil) & 19 & $0-10$ & 0.74 & 0.89 & 0.96 & 1.27 & 2 \\
\hline Labile-C (g C kg-1 soil) & 19 & $0-10$ & 1.68 & - & 2.73 & - & 5 \\
\hline CTC at pH $7.0\left(\mathrm{cmol}_{\mathrm{c}} \mathrm{kg}^{-1}\right.$ soil $)$ & 19 & $0-10$ & 10.1 & 10.0 & 11.1 & 11.7 & 2 \\
\hline \multicolumn{8}{|l|}{ Physical } \\
\hline MWD soil aggregates (mm) & 19 & $0-10$ & 2.65 & - & 3.76 & - & 5,6 \\
\hline Total soil porosity $\left(\mathrm{m}^{3} \mathrm{~m}^{-3}\right) \#$ & 19 & $0-12.5$ & 0.40 & 0.42 & 0.40 & 0.41 & 6 \\
\hline
\end{tabular}

$\uparrow \mathrm{SOC}=$ soil organic carbon; $\mathrm{CTC}=$ cation exchange capacity; $\mathrm{MWD}=$ mean weight diameter.

$\$$ Numbers indicate the time of the experiment when the soil variables were evaluated.

$\S \mathrm{O} / \mathrm{M}=$ black oat $/$ maize; $\mathrm{V} / \mathrm{M}=$ vetch/maize.

1) Zanatta et al. (2007); (2) Zanatta (2006); (3) Vargas and Scholles (2000); (4) Silveira (2007); (5) Conceição (2006); (6) Silva et al. (2006).

\# calculated from bulk soil density (1-bulk soil density/2.65), where $2.65 \mathrm{Mg} \mathrm{m}^{-3}$ is the particle density.

Source: Elaboration of the authors.

The beneficial effects of NT and high-biomass input cropping systems on soil quality have been extensively reported (AMADO et al., 2006; VIEIRA et al., 2007; DIECKOW et al., 2009). These effects mainly result from an increase in soil organic matter, which has a direct and indirect influence on most biological, chemical, and physical soil quality indicators (WANDER; BOLLERO, 1999; CONCEIÇÃO et al., 2005). Previous studies have indicated that the increase in soil organic matter and the consequent improvement in soil quality might be the main causes of the partial recovery in the strength of soil $\mathrm{CH}_{4}$ uptake under conservation management systems (KESSAVALOU et al., 1998; HÜTSCH, 2001).

\section{Soil $\mathrm{CH}_{4}$ fluxes and soil ammonium content}

Soil $\mathrm{CH}_{4}$ fluxes ranged from $-42 \pm 2$ to $38 \pm 16$ $\mu \mathrm{g} \mathrm{C} \mathrm{m} \mathrm{C}^{-2} \mathrm{~h}^{-1}$ (Figure 3). This range supports that in the published literature, with low $\mathrm{CH}_{4}$ fluxes being usually observed in non-flooded arable soils (SMITH et al., 2000; MOSIER et al., 2006; METAY et al., 2007; REGINA; ALAKUKKU, 2010). In a compilation of 63 studies conducted on tropical soils subjected to different land uses, more than $80 \%$ of the soils showed $\mathrm{CH}_{4}$ fluxes ranging from -50 to $50 \mu \mathrm{g} \mathrm{C} \mathrm{m}^{-2} \mathrm{~h}^{-1}$ (PRIEMÉ; CHRISTENSEN, 1999). 
Figure 3. Methane $\left(\mathrm{CH}_{4}\right)$ fluxes in subtropical Acrisol under long-term (19 years) tillage systems (conventional tillage and no-tillage) and cropping systems $(\mathrm{O} / \mathrm{M}=$ black oat/maize and $\mathrm{V} / \mathrm{M}=$ vetch/maize $)$. Vertical bars represent the mean standard error, and the dotted vertical line denotes the end limit of the post-management period considered in this study (90 days after cover-crop management).

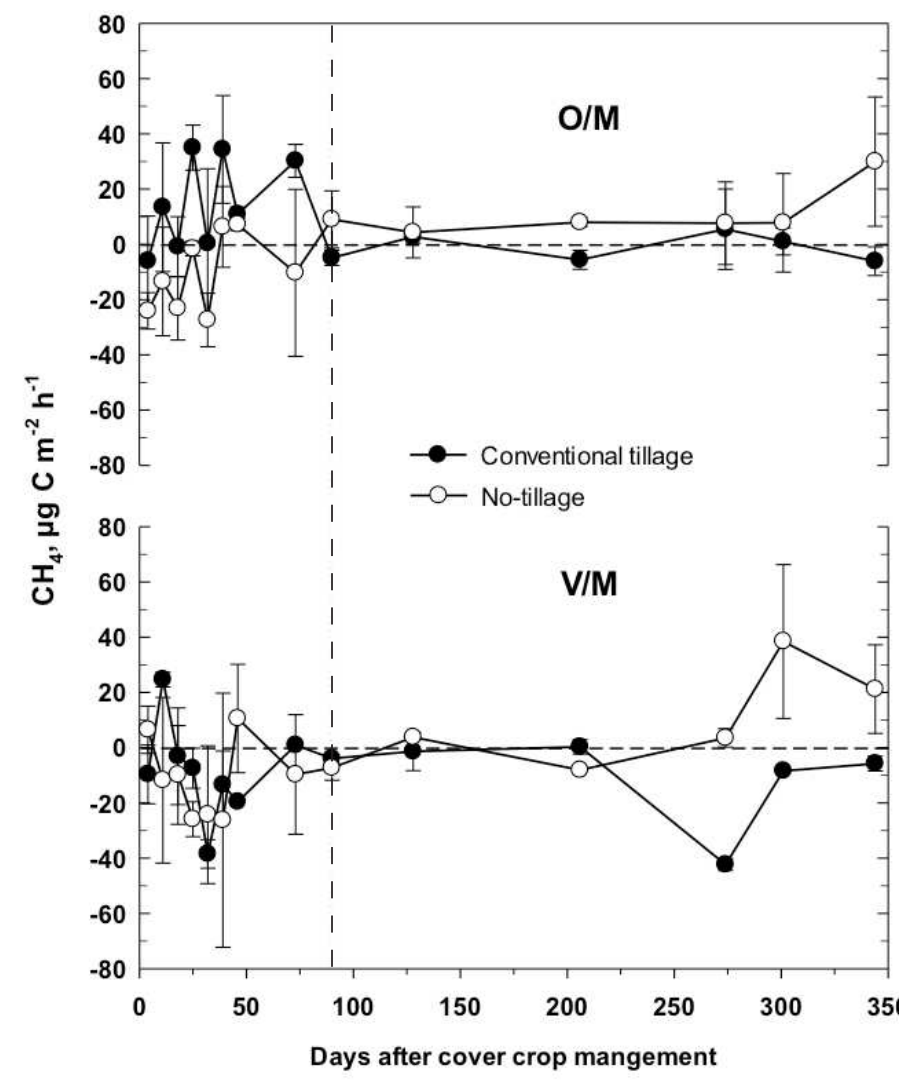

Source: Elaboration of the authors.

In general, the greatest oscillation in soil $\mathrm{CH}_{4}$ flux occurred during the first three months after the addition of vetch and black oat cover-crop residues to the soil (post-management period) for both tillage systems. In addition to the input of $\mathrm{C}$ and N-biomass from tillage operations, the largest oscillation of $\mathrm{CH}_{4}$ flux during the post-management period was probably related to the temperature and rainfall conditions that occur at the end of spring and the start of summer (Figure 2).

During the post-management period, an interaction between soil tillage and the cropping system was observed. Under the NT system, soils subjected to $\mathrm{V} / \mathrm{M}$ and $\mathrm{O} / \mathrm{M}$ cropping systems had a net oxidation of $\mathrm{CH}_{4}(-191 \pm 201$ and $-132 \pm$
$102 \mathrm{~g} \mathrm{C} \mathrm{ha}^{-1}$, respectively; Figure 4). In contrast, soil under the $\mathrm{CT}$ system tended to oxidize $\mathrm{CH}_{4}$ in the leguminous-based cropping system V/M (-162 $\left.\pm 71 \mathrm{~g} \mathrm{C} \mathrm{ha}^{-1}\right)$, but had a net $\mathrm{CH}_{4}$ emission under $\mathrm{O} / \mathrm{M}\left(+343 \pm 45 \mathrm{~g} \mathrm{C} \mathrm{ha}^{-1}\right)$. Lower soil organic carbon content and the addition of phytomass under the $\mathrm{CT} \mathrm{O} / \mathrm{M}$ system possibly reduced soil quality and, consequently, $\mathrm{CH}_{4}$ oxidation activity to a greater extent compared to CT V/M (JACINTHE; LAL, 2005; BAYER et al., 2012). Under the O/M cropping system, NT showed $\mathrm{CH}_{4}$ consumption because of the condition of undisturbed soil, which promotes positive effects on biological, chemical and physical soil quality indicators in comparison to CT (Table 1). Hütsch (1998) found that, after 
15 years, $\mathrm{CH}_{4}$ oxidation rates were 4.5 to 11 times greater in soil under NT management than under continuous tillage, with this result being supported by the findings of the current study.

Both soil management systems had a moderate effect on the $\mathrm{NH}_{4}^{+}-\mathrm{N}$ content of the soil (Figure 5); however, a significant relationship was not observed between this nutrient and soil $\mathrm{CH}_{4}$ fluxes. The $\mathrm{CH}_{4}$ oxidation of the $\mathrm{CT}$ V/M system (-162 $\left.\pm 71 \mathrm{~g} \mathrm{C} \mathrm{ha}^{-1}\right)$ was quite similar to that the $\mathrm{O} / \mathrm{M}$ and $\mathrm{V} / \mathrm{M}$ cropping systems under NT management (combined average of $-161 \pm 151 \mathrm{~g} \mathrm{C} \mathrm{ha}^{-1}$ ), despite having different $\mathrm{NH}_{4}^{+}-\mathrm{N}$ content (peaking at 16.6 and $5.6 \mathrm{mg} \mathrm{N} \mathrm{kg}^{-1}$ of soil, respectively; Figure 5). Thus, the results indicate that $\mathrm{NH}_{4}^{+}-\mathrm{N}$ does not have a suppressive effect on soil $\mathrm{CH}_{4}$ oxidation during the postmanagement period under both tillage systems, which contrasts with the findings widely reported in the published literature (POWLSON et al., 1997; BAGGS; CHEBII; NDUFA, 2006; ACTON; BAGGS, 2011). However, because a thick soil layer was sampled $(0-30 \mathrm{~cm})$ in the current study, some possible effects of $\mathrm{NH}_{4}^{+}-\mathrm{N}$ could have been masked (i.e., a dilution effect). $\mathrm{N}$ mineralization from crop residues under no-tillage system mainly occurs in the first few centimeters of the soil surface; hence, the $\mathrm{NH}_{4}^{+}$content of soils sampled closer to the surface might be greater than the $\mathrm{NH}_{4}^{+}$content of those sampled in the current study.

Figure 4. Methane $\left(\mathrm{CH}_{4}\right)$ fluxes accumulated in the post-management and annual periods in a subtropical Acrisol under long-term (19 years) tillage $(\mathrm{CT}=$ conventional tillage and $\mathrm{NT}=$ no-tillage $)$ and cropping systems $(\mathrm{O} / \mathrm{M}=$ black oat/maize and $\mathrm{V} / \mathrm{M}=$ vetch/maize). Means followed by same letter do not differ under Tukey's test at the 0.10 level.

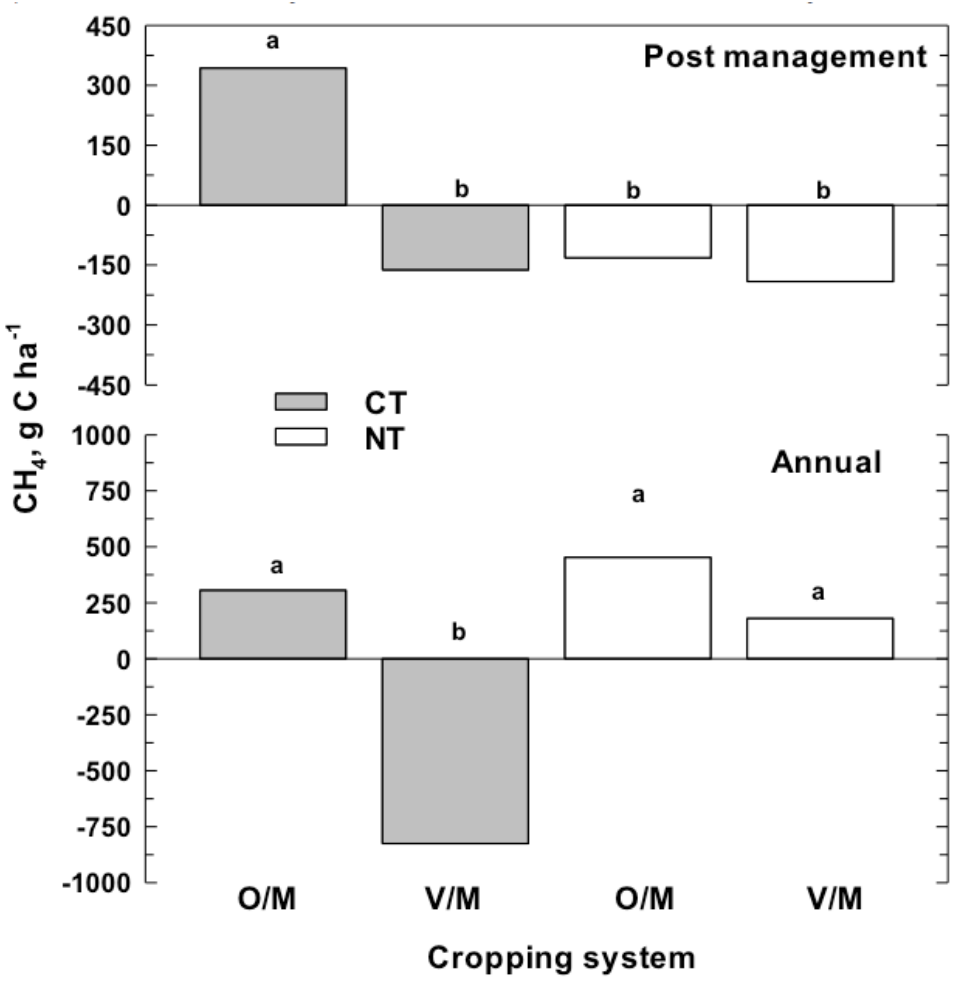

Source: Elaboration of the authors. 
Figure 5. $\mathrm{NH}_{4}^{+}-\mathrm{N}$ content in the $0-30$-cm soil layer of an Acrisol under long-term (19 years) tillage $(\mathrm{CT}=$ conventional tillage and $\mathrm{NT}=$ no-tillage $)$ and cropping systems $(\mathrm{O} / \mathrm{M}=$ black oat $/$ maize and $\mathrm{V} / \mathrm{M}=$ vetch $/ \mathrm{maize})$.

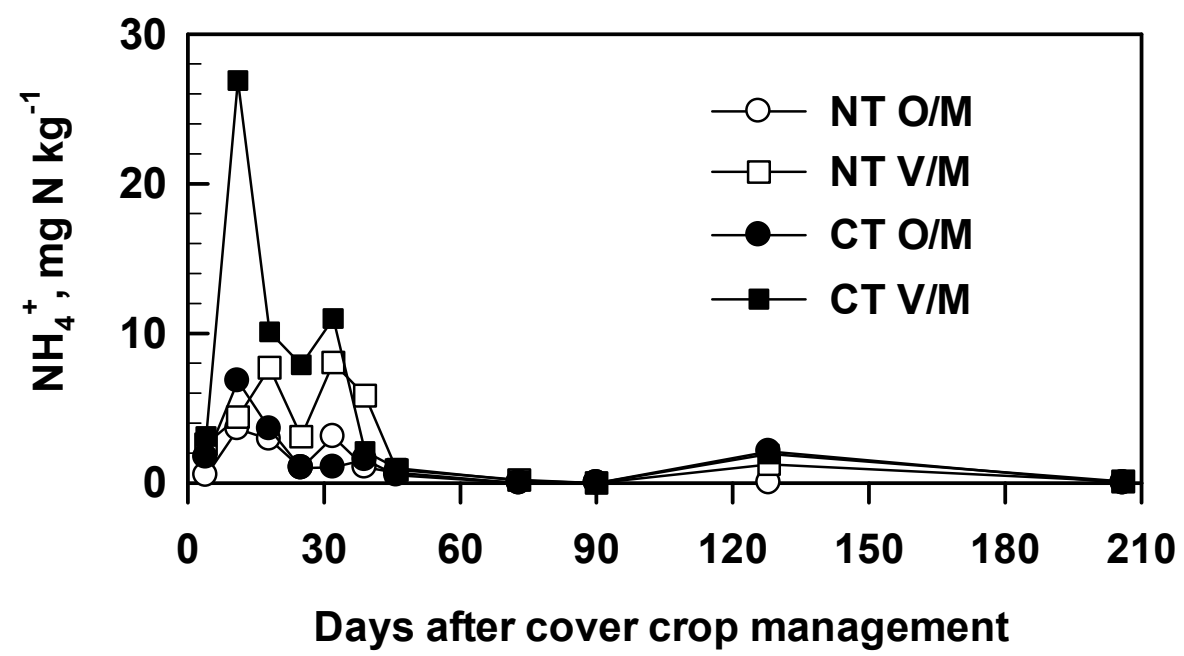

Source: Elaboration of the authors.

One possible cause for the non-manifestation of the suppressive effects of biologically fixed $\mathrm{N}$ on soil $\mathrm{CH}_{4}$ oxidation is that ammonification and $\mathrm{CH}_{4}$ oxidation processes occur in distinct soil zones. In NT soil, the mineralization of $\mathrm{N}$ from legume cover-crop residues primarily occurs in the topsoil layer, with most $\mathrm{NH}_{4}^{+}$being absorbed by the negative charges of soil colloids. However, in CT soil, the residues are mixed into the soil and ammonification occurs throughout the entire arable soil layer (0-17 cm in this study), with a slightly higher intensity near the soil surface because of the soil temperature being more favorable than that in deeper layers (UNGER, 1988). In temperate soils, the maximum $\mathrm{CH}_{4}$ oxidation zone seems to occur in the subsurface $(5-15 \mathrm{~cm})$ of NT soil (HÜTSCH, 2001). For CT soil, this zone is located below the arable layer (HÜTSCH, 1998; HÜTSCH, 2001) and, hence, separate from the soil layers where enzymatic competition between nitrification and $\mathrm{CH}_{4}$ oxidation processes would be stronger. Information on this parameter is not available for tropical and subtropical soils because of a paucity of published literature.
After the post-management period, $\mathrm{CH}_{4}$ fluxes generally decreased to background values. However, a net $\mathrm{CH}_{4}$ emission was observed in NT soil during the autumn and winter seasons (i.e., the period between 275 and 344 sampling days, Figure 3). The reason why this $\mathrm{CH}_{4}$ emission mainly occurred in NT soil is not clear; however, one plausible explanation might be because methanogenesis is favored by high soil moisture combined with a large amount of labile $\mathrm{C}$ in the first few centimeters of soil under this conservation management system (Table 1). Information about soil water content was not available for this experimental period, although high soil moisture conditions probably occurred because high-intensity rainfall was recorded (Figure 2). From April to June 2004, precipitation was 15 to $50 \%$ higher than normal. Hence, this influence on $\mathrm{CH}_{4}$ flux for a relatively long period during the winter affected the annual net $\mathrm{CH}_{4}$ emission in NT soil.

Annual-cumulative soil $\mathrm{CH}_{4}$ fluxes ranged from $-825 \pm 117$ to $453 \pm 185 \mathrm{~g} \mathrm{C} \mathrm{ha}^{-1}$ for the $\mathrm{CT} \mathrm{V/M}$ and NT O/M systems, respectively. Soil served as a minor source of $\mathrm{CH}_{4}$ under NT management for 
both $\mathrm{V} / \mathrm{M}$ and $\mathrm{O} / \mathrm{M}$ and under $\mathrm{CT}$ management for $\mathrm{O} / \mathrm{M}$, whereas it served as a minor sink under the CT legume-based cropping system (Figure 4). The tillage and cropping systems had a minimal impact on soil $\mathrm{CH}_{4}$ flux, which is similar to that observed in previous studies (JACINTHE; LAL, 2005; JACINTHE; LAL, 2006; ELDER; LAL, 2008; REGINA; ALAKUKKU, 2010).

Hence, the annual soil $\mathrm{CH}_{4}$ oxidation capacity was not related to the soil quality produced by the soil management systems (Table 1). This discrepancy might be due to the fact that the zone of maximum $\mathrm{CH}_{4}$ oxidation $(5-15 \mathrm{~cm})$ (HÜTSCH, 1998; JACINTHE; LAL, 2006) does not match to the soil profile layer where soil quality indicators are primarily improved $(0-5 \mathrm{~cm})$ (AMADO et al., 2006; ZANATTA et al., 2007; DIECKOW et al., 2009; VIEIRA et al., 2009). According to Hütsch (1998), the $\mathrm{CH}_{4}$ oxidation zone in the soil profile is near the substrate source (i.e., atmospheric $\mathrm{CH}_{4}$ ), and it is driven by the restraining factors such as high levels of $\mathrm{NH}_{4}^{+}$and the intense activity of competitors (such as nitrifiers), for example, among other factors.

On the basis of these findings, it may be hypothesized that, although soil quality improves in the surface layers after decades of conservation tillage management, this effect pushes the $\mathrm{CH}_{4}$ oxidation zone to deeper soil layers. This phenomenon might explain why several studies did not identify the beneficial effect of conservation practices on soil $\mathrm{CH}_{4}$ oxidation rates, even during medium- and long-term experiments. However, the postulation about $\mathrm{CH}_{4}$ metabolism in no-tilled soils requires confirmation via future studies focused on clarifying the potential of the conservation management system in the recovery of the $\mathrm{CH}_{4}$ sink capacity in tropical and subtropical soils.

\section{Conclusions}

The highest oscillation of methane fluxes occurs during the post-management period. The suppressive effect of biologically fixed $\mathrm{N}$ on methane oxidation was not observed during the period following cover crop management. The notillage and high biomass input management system significantly increased soil quality in comparison to conventionally tilled soil. However, small fluxes of methane were observed under all soil management systems, with no relationship being found between $\mathrm{CH}_{4}$ uptake and soil quality produced by the soil management systems used on this formerly degraded subtropical soil. On the basis of our results and published literature, we postulate that conservation management systems improve the methane oxidation and soil quality in distinct layers, which result in a slow effect of these management systems on the methane oxidation capacity.

\section{Acknowledgments}

This project was funded by the Brazilian Council for Scientific and Technologic Development (CNPq) and the Foundation of Research Support of Rio Grande do Sul State (Fapergs).

\section{References}

ACTON, S. D.; BAGGS, E. M. Interactions between N application rate, $\mathrm{CH}_{4}$ oxidation and $\mathrm{N}_{2} \mathrm{O}$ production in soil. Biogeochemistry, Dordrecht, v. 103, n. 1-3, p. 1526, 2011.

AMADO, T. J. C.; BAYER, C.; CONCEIÇÃO, P. C.; SPAGNOLLO, E.; CAMPOS, B. H. C.; VEIGA, M. Potential of carbon accumulation in no-till soils with intensive use and cover crops in southern Brazil. Journal of Environmental Quality, Madison, v. 35, n. 4, p. 15991607, 2006.

BAGGS, E. M.; CHEBII, J.; NDUFA, J. K. A short-term investigation of trace gas emissions following tillage and no-tillage of agroforestry residues in western Kenya. Soil \& Tillage Research, Amsterdam, v. 90, n. 1-2, p. 69-76, 2006.

BALL, B. C.; SCOTT, A.; PARKER, J. P. Field $\mathrm{N}_{2} \mathrm{O}, \mathrm{CO}_{2}$ and $\mathrm{CH}_{4}$ fluxes in relation to tillage, compaction and soil quality in Scotland. Soil \& Tillage Research, Amsterdam, v. 53, n. 1, p. 29-39, 1999. 
BAYER, C.; GOMES, J.; VIEIRA, F. C. B.; ZANATTA, J.A.; PICCOLO, M. D.; DIECKOW, J. Methane emission from soil under long-term no-till cropping systems. Soil \& Tillage Research, Amsterdam, v. 124, n. 1, p. 1-7, 2012.

BOECKX, P.; VANCLEEMPUT, O.; VILLARALVO, I. Methane oxidation in soils with different textures and land use. Nutrient Cycling in Agroecosystems, Dordrecht, v. 49, n. 1-3, p. 91-95, 1997.

CONCEIÇÃO, P. C. Agregação e proteção da matéria orgânica em dois solos do Sul do Brasil. 2006. Tese (Doutorado em Ciência do Solo) - Universidade Federal do Rio Grande do Sul, Porto Alegre.

CONCEIÇÃO, P. C.; AMADO, T. J. C.; MIELNICZUK, J.; SPAGNOLLO, E. Qualidade do solo em sistemas de manejo avaliada pela dinâmica da matéria orgânica e atributos relacionados. Revista Brasileira de Ciência do Solo, Viçosa, v. 29, n. 5, p. 777-788, 2005.

DIECKOW, J.; BAYER, C.; CONCEICAO, P. C.; ZANATTA, J. A.; MARTIN-NETO, L.; MILORI, D. B. M.; SALTON, J. C.; MACEDO, M. M.; MIELNICZUK, J.; HERNANI, L. C. Land use, tillage, texture and organic matter stock and composition in tropical and subtropical Brazilian soils. European Journal of Soil Science, Malden, v. 60, n. 2, p. 240-249, 2009.

ELDER, J. W.; LAL, R. Tillage effects on gaseous emissions from an intensively farmed organic soil in North Central Ohio. Soil \& Tillage Research, Amsterdam, v. 98, n. 1, p. $45-55,2008$.

GOMES, J.; BAYER, C.; COSTA, F. D.; PICCOLO, M. D.; ZANATTA, J. A.; VIEIRA, F. C. B.; SIX, J. Soil nitrous oxide emissions in long-term cover cropsbased rotations under subtropical climate. Soil \& Tillage Research, Amsterdam, v. 106, n. 1, p. 36-44, 2009.

HÜTSCH, B. W. Tillage and land use effects on methane oxidation rates and their vertical profiles in soil. Biology and Fertility of Soils, New York, v. 27, n. 3, p. 284-292, 1998.

HÜTSCH, B. W. Methane oxidation in non-flooded soils as affected by crop production - invited paper. European Journal of Agronomy, Amsterdam, v. 14, n. 4, p. 237260, 2001.

IPCC. Climate Change 2007: the physical science basis Contribution of working group I to the fourth assessment report of the intergovernmental panel on climate change. Cambridge: Cambridge University Press, 2007. 996 p.

IUSS. World Reference Base for Soil Resources 2006. Rome: FAO, 2006. 132 p.
JACINTHE, P. A.; LAL, R. Labile carbon and methane uptake as affected by tillage intensity in a Mollisol. Soil \& Tillage Research, Amsterdam, v. 80, n. 1-2, p. 35-45, 2005.

JACINTHE, P. A.; LAL, R. Methane oxidation potential of reclaimed grassland soils as affected by management. Soil Science, Philadelphia, v. 171, n. 10, p. 772-783, 2006.

JANTALIA, C. P.; SANTOS, H. P.; URQUIAGA, S.; BODDEY, R. M.; ALVES, B. J. R. Fluxes of nitrous oxide from soil under different crop rotations and tillage systems in the south of Brazil. Nutrient Cycling in Agroecosystems, Dordrecht, v. 82, n. 2, p. 161-173, 2008.

KESSAVAlOU, A.; MOSIER, A. R.; DORAN, J. W.; DRIJBER, R. A.; LYON, D. J.; HEINEMEYER, O. Fluxes of carbon dioxide, nitrous oxide, and methane in grass sod and winter wheat-fallow tillage management. Journal of Environmental Quality, Madison, v. 27, n. 5, p. 1094-1104, 1998.

MAXFIELD, P. J.; BRENNAND, E. L.; POWLSON, D. S.; EVERSHED, R. P. Impact of land management practices on high-affinity methanotrophic bacterial populations: evidence from long-term sites at Rothamsted. European Journal of Soil Science, Malden, v. 62, n. 1, p. 56-68, 2011.

MCLAIN, J. E. T.; AHMANN, D. M. Increased moisture and methanogenesis contribute to reduced methane oxidation in elevated $\mathrm{CO}_{2}$ soils. Biology and Fertility of Soils, New York, v. 44, n. 4, p. 623-631, 2008.

METAY, A.; OLIVER, R.; SCOPEL, E.; DOUZET, J. M.; ALVES MOREIRA, J. A.; MARAUX, F.; FEIGL, B. J.; FELLER, C. $\mathrm{N}_{2} \mathrm{O}$ and $\mathrm{CH}_{4}$ emissions from soils under conventional and no-till management practices in Goiania (Cerrados, Brazil). Geoderma, Amsterdam, v. 141, n. 1-2, p. 78-88, 2007.

MOJEREMANE, W.; REES, R. M.; MENCUCCINI, M. Effects of site preparation for afforestation on methane fluxes at Harwood Forest, NE England. Biogeochemistry, Dordrecht, v. 97, n. 1, p. 89-107, 2010.

MOSIER, A. R.; HALVORSON, A. D.; REULE, C. A.; LIU, X. J. J. Net global warming potential and greenhouse gas intensity in irrigated cropping systems in northeastern Colorado. Journal of Environmental Quality, Madison, v. 35, n. 4, p. 1584-1598, 2006.

MULVANEY, R. L. Nitrogen - inorganic forms. In: SPARKS, D. L.; PAGE, A. L. et al. (Ed.). Methods of soil analysis: part 3 chemical methods. Madison: Soil Science Society of America, 1996. p. 1123-1184. 
POWLSON, D. S.; GOULDING, K. W. T.; WILLISON, T. W.; WEBSTER, C. P.; HUTSCH, B. W. The effect of agriculture on methane oxidation in soil. Nutrient Cycling in Agroecosystems, Dordrecht, v. 49, n. 1-3, p. 59-70, 1997.

PRIEMÉ, A.; CHRISTENSEN, S. Methane uptake by a selection of soils in Ghana with different land use. Journal of Geophysical Research-Atmospheres, Washington, v. 104, n. D19, p. 23617-23622, 1999.

REGINA, K.; ALAKUKKU, L. Greenhouse gas fluxes in varying soils types under conventional and no-tillage practices. Soil \& Tillage Research, Amsterdam, v. 109, n. 2, p. 144-152, 2010.

SILVA, M. A. S.; MAFRA, A. L.; ALBUQUERQUE, J. A.; ROSA, J. D.; BAYER, C.; MIELNICZUK, J. Propriedades físicas e teor de carbono orgânico de um Argissolo Vermelho sob distintos sistema de uso e manejo. Revista Brasileira de Ciência do Solo, Viçosa, v. 30, n. 2, p. 329-337, 2006.

SILVEIRA, A. O. Atividades enzimáticas como indicadores biológicos da qualidade de solos agrícolas do Rio Grande do Sul. 2007. Dissertação (Mestrato em Ciência do Solo) - Universidade Federal do Rio Grande do Sul, Porto Alegre.

SMITH, K. A.; DOBBIE, K. E.; BALL, B. C.; BAKKEN, L. R.; SITAULA, B. K.; HANSEN, S.; BRUMME, R.; BORKEN, W.; CHRISTENSEN, S.; PRIEME, A.; FOWLER, D.; MACDONALD, J. A.; SKIBA, U.; KLEMEDTSSON, L.; KASIMIR-KLEMEDTSSON, A.; DEGORSKA, A.; ORLANSKI, P. Oxidation of atmospheric methane in Northern European soils, comparison with other ecosystems, and uncertainties in the global terrestrial sink. Global Change Biology, Malden, v. 6, n. 7, p. 791-803, 2000.

STIEHL-BRAUN, P. A.; POWLSON, D. S.; POULTON, P. R.; NILDAUS, P. A. Effects of $\mathrm{N}$ fertilizers and liming on the micro-scale distribution of soil methane assimilation in the long-term Park Grass experiment at Rothamsted. Soil Biology and Biochemistry, Oxford v. 43, n. 5, p. 1034-1041, 2011.

SUWANWAREE, P.; ROBERTSON, G. P. Methane oxidation in forest, successional, and no-till agricultural ecosystems: Effects of nitrogen and soil disturbance. Soil Science Society of American Journal, Madison, v. 69, n. 6, p. 1722-1729, 2005.
UNGER, P. W. Residue management effects on soil Temperature. Soil Science Society of American Journal, Madison, v. 52, n. 6, p. 1777-1782, 1988.

USSIRI, D. A. N.; LAL, R.; JARECKI, M. K. Nitrous oxide and methane emissions from long-term tillage under a continuous corn cropping system in Ohio. Soil \& Tillage Research, Amsterdam, v. 104, n. 2, p. 247-255, 2009.

VARGAS, L. K.; SCHOLLES, D. Biomassa microbiana e produção de $\mathrm{C}-\mathrm{CO}_{2}$ e $\mathrm{N}$ mineral de um Podzólico Vermelho-Escuro submetido a diferentes sistemas de manejo. Revista Brasileira de Ciência do Solo, Viçosa, v. 24, p. 35-42, 2000.

VIEIRA, F. C. B.; BAYER, C.; ZANATTA, J. A.; DIECKOW, J.; MIELNICZUK, J.; HE, Z. L. Carbon management index based on physical fractionation of soil organic matter in an Acrisol under long-term no-till cropping systems. Soil and Tillage Research, Amsterdam, v. 96, n. 1-2, p. 195-204, 2007.

VIEIRA, F. C. B.; BAYER, C.; ZANATTA, J. A.; MIELNICZUK, J.; SIX, J. Building up organic matter in a Subtropical Paleudult under legume cover-crop-based rotations. Soil Science Society of American Journal, Madison, v. 73, n. 5, p. 1699-1706, 2009.

WANDER, M. M.; BOLLERO, G. A. Soil quality assessment of tillage impacts in Illinois. Soil Science Society of American Journal, Madison, v. 63, n. 4, p. 961971, 1999.

WILLISON, T. W.; WEBSTER, C. P.; GOULDING, K. W. T.; POWLSON, D. S. Methane oxidation in temperate soils: effects of land use and the chemical form of nitrogen fertilizer. Chemosphere, Oxford, v. 30, n. 3, p. 539-546, 1995.

ZANATTA, J. A. Estoque e labilidade do carbono em frações da matéria orgânica de um Argissolo afetados por sistemas de manejo do solo. 2006. Dissertação (Mestrado em Ciência do Solo) - Universidade Federal do Rio Grande do Sul, Porto Alegre.

ZANATTA, J. A.; BAYER, C.; DIECKOW, J.; VIEIRA, F. C. B.; MIELNICZUK, J. Soil organic carbon accumulation and carbon costs related to tillage, cropping systems and nitrogen fertilization in a subtropical Acrisol. Soil \& Tillage Research, Amsterdam, v. 94, n. 2, p. 510519, 2007. 